\title{
Are Opioids Needed to Treat Chronic Low Back Pain? A Review of Treatment Options and Analgesics in Development
}

This article was published in the following Dove Press journal: Journal of Pain Research

Jeffrey Gudin ${ }^{1,2}$

Andrew G Kaufman'

Samyadev Datta (iD ${ }^{1,3}$

'Department of Anesthesiology, Rutgers New Jersey Medical School, Newark, NJ, USA; ${ }^{2}$ Department of Anesthesiology, Englewood Hospital and Medical Center, Englewood, NJ, USA; ${ }^{3}$ Center for Pain Management, Hackensack, NJ, USA
Correspondence: Jeffrey Gudin

Englewood Hospital and Medical Center,

350 Engle St \#1808, Englewood, NJ

0763I, USA

Tel + I 20I-894-3322

Email healthmd@optonline.net
Abstract: The continued prevalence of chronic low back pain (CLBP) is a testament to our lack of understanding of the potential causes, leading to significant treatment challenges. CLBP is the leading cause of years lived with disability and the fifth leading cause of disability-adjusted life-years. No single non-pharmacologic, pharmacologic, or interventional therapy has proven effective as treatment for the majority of patients with CLBP. Although non-pharmacologic therapies are generally helpful, they are often ineffective as monotherapy and many patients lack adequate access to these treatments. Noninvasive treatment measures supported by evidence include physical and chiropractic therapy, yoga, acupuncture, and non-opioid and opioid pharmacologic therapy; data suggest a moderate benefit, at most, for any of these therapies. Until our understanding of the pathophysiology and treatment of CLBP advances, clinicians must continue to utilize rational multimodal treatment protocols. Recent Centers for Disease Control and Prevention guidelines for opioid prescribing recommend that opioids not be utilized as first-line therapy and to limit the doses when possible for fear of bothersome or dangerous adverse effects. In combination with the current opioid crisis, this has caused providers to minimize or eliminate opioid therapy when treating patients with chronic pain, leaving many patients suffering despite optimal nonopioid therapies. Therefore, there remains an unmet need for effective and tolerable opioid receptor agonists for the treatment of CLBP with improved safety properties over legacy opioids. There are several such agents in development, including opioids and other agents with novel mechanisms of action. This review critiques non-pharmacologic and pharmacologic treatment modalities for CLBP and examines the potential of novel opioids and other analgesics that may be a useful addition to the treatment options for patients with chronic pain.

Keywords: non-pharmacologic, opioid, chronic low back pain, analgesia

\section{Introduction}

Low back pain (LBP) affects over half a billion people around the world, according to 2015 statistics from the Global Burden of Disease study. ${ }^{1}$ In the United States, the 2015 age-adjusted prevalence of LBP in adults ( $\geq 18$ years) was $29 \% .^{2}$ Among patients with LBP, approximately $26 \%$ will have persistent disabling pain at 3 to 6 months and $21 \%$ at 1 year. $^{3}$ Chronic LBP (CLBP), which is commonly defined as lumbar pain persisting for $>3$ months, ${ }^{4}$ has a $13 \%$ point prevalence among US adults 20 to 69 years old, with the highest prevalence among those ages 50 to 69 years. ${ }^{5}$

Pain affects a large number of people - the Centers for Disease Control and Prevention (CDC) estimates that among the 50 million Americans with chronic 
pain approximately 20 million have "high-impact" chronic pain, defined as pain severe enough to frequently limit life or work activities. ${ }^{6}$ Included in that population are those with CLBP, which also has a significant impact on quality of life. For example, CLBP is associated with a higher prevalence of comorbidities, including an increased risk of depression, anxiety, and sleep disturbances, and higher healthcare costs. ${ }^{5,7}$ LBP is the leading cause of years lived with disability and the fifth leading cause of disabilityadjusted life-years. ${ }^{8}$

The continued prevalence of CLBP is a testament to the limitations of the current treatment landscape. Although spinal cord stimulation and other device technology have improved and novel drugs and devices are on the horizon, clinicians still need safer and more effective pharmaceutical options to provide pain relief and improvement in function while minimizing the risks of currently available analgesics. This review critiques nonpharmacologic and pharmacologic treatment modalities and examines the potential of novel opioids and other analgesics under development for CLBP.

\section{Common Causes for LBP}

Common causes for LBP include muscle spasm, disc pathology, nerve root impingement (resulting in radiculopathy), spinal stenosis (with or without neurogenic claudication), and joint issues involving the intraarticular facet or sacroiliac joints. More advanced pathological causes of acute and chronic LBP include vertebral fractures, axial spondyloarthropathies, cancer metastases, and spinal infections. ${ }^{9}$ However, most people suffer with CLBP that has no recognized specific cause. The cervical and lumbar paravertebral region contain many muscle groups, which control nearly all spinal motions and posture. Physical and mental stressors contribute to spasm of these muscles, with resulting postural changes and non-specific pain. There are a multitude of treatments available for nonspecific CLBP, some of which will be reviewed below. Chemical radiculitis may be the source of radiating leg pain in patients with discogenic disease without radiographic evidence of disc herniation. Imaging studies such as magnetic resonance imaging (MRI) frequently document asymptomatic findings, including disc herniations in $20 \%$ of patients without LBP less than age 60 years and $36 \%$ above age 60. ${ }^{10}$ Symptomatic findings on MRI may include disc herniation or high-intensity zone lesions which are often considered as pain generators. ${ }^{11}$ While exact mechanisms are poorly understood, evidence indicates that multiple pathophysiological pathways are associated with nonspecific LBP. For example, gluteal muscle spasm can lead to symptoms suggestive of radicular pain, or "pseudosciatica" symptoms often referred to as piriformis syndrome. ${ }^{12}$ Another challenging fact is that discogenic pain may only be axial in nature; studies have shown a correlation between vertebral endplate (Modic) changes seen on MRI scans and LBP. ${ }^{13,14}$

\section{Treatment Guidelines}

The American College of Physicians (ACP) guidelines for noninvasive treatments of CLBP recommend starting patients with nonpharmacologic treatment such as exercise, multidisciplinary rehabilitation, acupuncture, and mindfulness-based stress reduction. ${ }^{15}$ For patients with insufficient response to nonpharmacologic therapy, the ACP recommends nonsteroidal anti-inflammatory drugs (NSAIDs) as first-line drug therapy and tramadol or duloxetine for second-line therapy. Opioids may be considered for patients who have not responded to conventional therapies, after weighing the risks and benefits for each individual. Opioids should be used in conjunction with other treatments, in alignment with the CDC guideline for prescribing opioids for chronic pain. ${ }^{16-18}$ This guideline provides recommendations to primary care clinicians about the safe and effective prescribing of opioids to improve pain management and patient safety. The American Society of Interventional Pain Physicians (ASIPP) guidelines also describe similar measures for responsible and safe prescription of opioids to treat patients with chronic noncancer pain. ${ }^{19}$

\section{Effectiveness of Interventional and Surgical Treatment of LBP}

A review of spine surgery including discectomy and fusion, as well as interventional pain procedures such as epidural and facet injections is outside the scope of this review. These procedures are performed by a diverse population of clinicians who utilize a variety of techniques, often without consensus regarding optimal practice. Although most studies regarding the utility of epidural steroid injections for radicular pain due to lumbar disc herniation report significant short-term improvements, epidurals do not appear to be as effective in altering outcomes when treating primarily axial pain or spinal stenosis. ${ }^{20}$ A 2016 review of the effectiveness and risks of fluoroscopically guided lumbar interlaminar epidural steroid injections noted a low body of 
evidence for the treatment of axial pain regardless of etiology. ${ }^{21}$ In the absence of severe or progressive neurological deficit, surgery may be an option for patients with refractory LBP who have not responded to conservative treatments. Unfortunately, overall failure rates of lumbar spine surgery range from $10 \%$ to $46 \%{ }^{22}$ Both patient and operative factors contribute to surgery failure.

\section{Pros and Cons of Nonpharmacologic Therapies}

Table 1 summarizes the evidence for nonpharmacological therapies - such as acupuncture, cognitive-behavioral therapies (CBT), and spinal manipulation-according to a 2017 systematic review by the ACP which graded evidence from comparative studies in patients with CLBP. ${ }^{23}$ This review reported that several nonpharmacologic therapies for CLBP were associated with small to moderate effects on pain that were usually short term.

A 2018 comparative effectiveness review of chronic pain studies reported only slight improvements in function and pain in patients with CLBP following short-term treatment with various nonpharmacological treatments compared with usual care or inactive controls. ${ }^{24}$ Of the interventions with sufficient evidence to evaluate longterm effects, exercise had no effect on function and a moderate effect on pain; psychological therapies had a slight effect on both function and pain; acupuncture had no effect on function and a slight effect on pain; and mindfulness practices and multidisciplinary rehabilitation had no effect on both function and pain. The authors rated the strength of the evidence for short-term effects as moderate or low depending on the intervention, and low for long-term effects for all interventions. Most of the analyzed studies involved patients with moderate baseline pain intensity (ie, $>5$ on a $0-10$ numeric rating scale). None of the studies compared the interventions with opioid therapy, and few data were reported on adherence and adverse events (AEs).

A 2017 Cochrane systematic review found the evidence supporting the use of 3 and 6 months of yoga compared with non-exercise controls was low to moderate for improving back-related function and, while it was slightly better for pain, it did not meet the threshold for a clinically significant effect. ${ }^{25}$ Similarly, a 2015 Cochrane systematic review found low to moderate quality evidence supporting the use of Pilates compared with minimal interventions to treat pain and disability in adults with LBP (acute, subacute, or chronic). ${ }^{26}$ An open-label-randomized controlled trial (RCT) in 324 adults with nonspecific CLBP ( $\geq 3$ months) found that 8 weeks of mindfulnessbased stress reduction and CBT were associated with greater improvement in functional limitations, as assessed by the modified Roland Disability Questionnaire, and in self-reported back pain compared with usual care at 26 and 52 weeks. ${ }^{27}$ A meta-analysis of RCTs published from 2000 to 2014 found a small to moderate effect at reducing pain intensity with manipulation and mobilization versus other active treatments (eg, acupuncture, physical therapy, exercise) in patients with CLBP. ${ }^{28} \mathrm{~A}$ cross-sectional analysis of US health insurance claims data from 2007 to 2017 linked early physical therapy to an approximately $10 \%$ statistically significant reduction in oral morphine milligram equivalent (MME) use for LBP $(p=0.046)$, shoulder pain $(p=0.03)$, and knee pain $(p=0.007)$ in adults with no previous opioid prescriptions. ${ }^{29}$ Although generally considered beneficial, with studies supporting minimal to moderate improvement in CLBP, the effectiveness of physical rehabilitation has not been well supported by systematic reviews. For example, 2011 and 2018 reviews concluded that there was insufficient data to support these interventions due to the heterogeneity of patients and interventions. ${ }^{30,31}$

To summarize, although nonpharmacological therapies are generally helpful, many patients continue to experience significant CLBP as the data above suggest the benefits may be short term or ineffective as monotherapy.

\section{Pros and Cons of Nonopioid Pharmacologic Therapies}

A 2017 systematic review by the ACP graded the evidence for pharmacologic therapies compared with placebo for CLBP (Table 2). ${ }^{32}$ This review found that several medications for CLBP were associated with small to moderate, primarily short-term effects on pain, making it impossible to extrapolate these results to long-term use of these agents for CLBP. These authors noted that newer evidence showed acetaminophen to be ineffective for acute LBP and duloxetine to have modest effects for CLBP.

A 2016 Cochrane systematic review of 6 RCTs found a small, albeit statistically significant treatment effect with NSAIDs compared with placebo in reducing pain and disability in patients with CLBP. ${ }^{33,34}$ The authors deemed the evidence to be of low quality and, after the exclusion of studies with high risk of bias, the difference lost its statistical 
Table I ACP Grading of Nonpharmacologic Modalities for CLBP (Adapted from Chou et al) ${ }^{23}$

\begin{tabular}{|c|c|c|c|c|c|c|}
\hline \multirow[t]{2}{*}{ Modality Comparison } & \multicolumn{3}{|l|}{ Pain } & \multicolumn{3}{|l|}{ Function } \\
\hline & $\begin{array}{l}\text { Magnitude of } \\
\text { Effect }\end{array}$ & Evidence & $\begin{array}{l}\text { Strength } \\
\text { of } \\
\text { Evidence }\end{array}$ & $\begin{array}{l}\text { Magnitude } \\
\text { of Effect }\end{array}$ & Evidence & $\begin{array}{l}\text { Strength } \\
\text { of } \\
\text { Evidence }\end{array}$ \\
\hline $\begin{array}{l}\text { Acupuncture vs no } \\
\text { acupuncture }\end{array}$ & Moderate & I SR (4 RCTs) & Moderate & Moderate & I SR (3 RCTs) & Moderate \\
\hline $\begin{array}{l}\text { Acupuncture vs sham } \\
\text { acupuncture }\end{array}$ & Moderate & $\begin{array}{l}\text { I SR }(4 \text { RCTs })+5 \\
\text { RCTs }\end{array}$ & Low & No effect & $\begin{array}{l}\text { I SR (4 RCTs) + } 5 \\
\text { RCTs }\end{array}$ & Low \\
\hline CBT vs waitlist control & Moderate & I SR (5 RCTs) & Low & No effect & I SR (4 RCTs) & Low \\
\hline $\begin{array}{l}\text { EMG biofeedback vs } \\
\text { waitlist or placebo }\end{array}$ & Moderate & I SR (3 RCTs) & Low & No effect & I SR (3 RCTs) & Low \\
\hline Exercise vs usual care & Small & I SR (I9 RCTs) + I SR & Moderate & Small & I SR (I7 RCTs) + I SR & Moderate \\
\hline Massage vs usual care & No effect & I RCT & Low & $\begin{array}{l}\text { Unable to } \\
\text { estimate }\end{array}$ & 2 RCTs & Insufficient \\
\hline $\begin{array}{l}\text { MBSR vs usual care or } \\
\text { education }\end{array}$ & Small & 3 RCTs & Moderate & Small & 3 RCTs & Moderate \\
\hline $\begin{array}{l}\text { Motor control exercise vs } \\
\text { minimal intervention }\end{array}$ & $\begin{array}{l}\text { Short to long } \\
\text { term: } \\
\text { Moderate }\end{array}$ & I SR (2 RCTs) & Low & $\begin{array}{l}\text { Small (short } \\
\text { to long term) }\end{array}$ & I SR (3 RCTs) & Low \\
\hline $\begin{array}{l}\text { Multidisciplinary rehab vs } \\
\text { no multidisciplinary rehab }\end{array}$ & Moderate & I SR (5 RCTs) & Low & Small & I SR (3 RCTs) & Low \\
\hline $\begin{array}{l}\text { Multidisciplinary rehab vs } \\
\text { usual care }\end{array}$ & $\begin{array}{l}\text { Short term: } \\
\text { Moderate } \\
\text { Long term: } \\
\text { Small } \\
\text { (favors rehab) }\end{array}$ & $\begin{array}{l}\text { Short term: I SR } \\
\text { (9 RCTs) } \\
\text { Long term: I SR } \\
\text { (7 RCTs) }\end{array}$ & Moderate & $\begin{array}{l}\text { Short term: } \\
\text { Small } \\
\text { Long term: } \\
\text { Small }\end{array}$ & $\begin{array}{l}\text { Short term: I SR } \\
\text { (9 RCTs) } \\
\text { Long term: I SR } \\
\text { (7 RCTs) }\end{array}$ & Moderate \\
\hline $\begin{array}{l}\text { Operant therapy vs waitlist } \\
\text { control }\end{array}$ & Small & I SR (3 RCTs) & Low & No effect & I SR (2 RCTs) & Low \\
\hline $\begin{array}{l}\text { Progressive relaxation vs } \\
\text { waitlist control }\end{array}$ & Moderate & I SR (3 RCTs) & Low & Moderate & I SR (3 RCTs) & Low \\
\hline $\begin{array}{l}\text { Spinal manipulation vs } \\
\text { sham manipulation }\end{array}$ & No effect & I SR (3 RCTs) + I RCT & Low & $\begin{array}{l}\text { Unable to } \\
\text { estimate }\end{array}$ & I RCT & - \\
\hline $\begin{array}{l}\text { Spinal manipulation vs inert } \\
\text { treatment }\end{array}$ & Small & 7 RCTs & Low & - & - & - \\
\hline $\begin{array}{l}\text { Tai chi vs waitlist or no tai } \\
\text { chi }\end{array}$ & Moderate & 2 RCTs & Low & Small & I RCT & Low \\
\hline Yoga vs usual care & Moderate & I RCT & Low & Moderate & I RCT & Low \\
\hline Yoga vs education & $\begin{array}{l}\text { Short term: } \\
\text { Small } \\
\text { Longer term: } \\
\text { No effect }\end{array}$ & $\begin{array}{l}5 \text { RCTs (short term + } \\
4 \text { RCTs (longer term) }\end{array}$ & Low & $\begin{array}{l}\text { Short term: } \\
\text { Small } \\
\text { Longer term: } \\
\text { No effect }\end{array}$ & $\begin{array}{l}5 \text { RCTs (short term) + } \\
4 \text { RCTs (longer term) }\end{array}$ & Low \\
\hline
\end{tabular}

Abbreviations: ACP, American College of Physicians; CBT, cognitive behavioral therapy; CLBP, chronic low back pain; EMG, electromyography; MBSR, mindfulness-based stress reduction; RCT, randomized-controlled trial; SR, systematic review. 
Table 2 ACP Grading of Pharmacologic Therapies versus Placebo for CLBP 32

\begin{tabular}{|c|c|c|c|c|c|c|}
\hline \multirow[t]{2}{*}{ Drug } & \multicolumn{3}{|l|}{ Pain } & \multicolumn{3}{|l|}{ Function } \\
\hline & Magnitude of Effect & Evidence & $\begin{array}{l}\text { Strength of } \\
\text { Evidence }\end{array}$ & $\begin{array}{l}\text { Magnitude } \\
\text { of Effect }\end{array}$ & Evidence & $\begin{array}{l}\text { Strength of } \\
\text { Evidence }\end{array}$ \\
\hline Acetaminophen & No evidence & - & - & No evidence & - & - \\
\hline NSAIDs & Small to moderate & $\begin{array}{l}\text { I SR (4 } \\
\text { RCTs) } \\
2 \text { RCTs }\end{array}$ & Moderate & None to small & 4 RCTs & Low \\
\hline Opioids (strong) & Small & $\begin{array}{l}\text { I SR (6 } \\
\text { RCTs) } \\
4 \text { RCTs }\end{array}$ & Moderate & Small & $\begin{array}{l}\text { I SR (4 } \\
\text { RCTs) } \\
4 \text { RCTs }\end{array}$ & Moderate \\
\hline $\begin{array}{l}\text { Opioids (buprenorphine } \\
\text { patch or sublingual) }\end{array}$ & Small & 3 RCTs & Low & $\begin{array}{l}\text { Unable to } \\
\text { estimate }\end{array}$ & 3 RCTs & Insufficient \\
\hline Tramadol & Moderate & $\begin{array}{l}\text { I SR (5 } \\
\text { RCTs) } \\
2 \text { RCTs }\end{array}$ & Moderate & Small & $\begin{array}{l}\text { I SR (5 } \\
\text { RCTs) } \\
2 \text { RCTs }\end{array}$ & Moderate \\
\hline Skeletal muscle relaxants & Unable to estimate & 3 RCTs & Insufficient & - & - & - \\
\hline $\begin{array}{l}\text { Benzodiazepines } \\
\text { (tetrazepam) }\end{array}$ & $\begin{array}{l}\text { Failure to improve at I0-14 days: RR, } \\
0.7 \mathrm{I}(95 \% \mathrm{Cl}, 0.54-0.93)\end{array}$ & $\begin{array}{l}\text { I SR (2 } \\
\text { RCTs) }\end{array}$ & Low & - & - & - \\
\hline Tricyclic antidepressants & No effect & $\begin{array}{l}\text { I SR (4 } \\
\text { RCTs) }\end{array}$ & Moderate & No effect & $\begin{array}{l}\text { I SR (2 } \\
\text { RCTs) }\end{array}$ & Low \\
\hline Antidepressants (SSRIs) & No effect & $\begin{array}{l}\text { I SR (3 } \\
\text { RCTs) }\end{array}$ & Moderate & - & - & - \\
\hline $\begin{array}{l}\text { Antidepressants } \\
\text { (duloxetine) }\end{array}$ & Small & 3 RCTs & Moderate & Small & 3 RCTs & Moderate \\
\hline Gabapentin/pregabalin & Unable to estimate & 2 RCTs & Insufficient & $\begin{array}{l}\text { Unable to } \\
\text { estimate }\end{array}$ & 2 RCTs & Insufficient \\
\hline
\end{tabular}

Abbreviations: ACP, American College of Physicians; Cl, confidence interval; CLBP, chronic low back pain; NSAID, nonsteroidal anti-inflammatory drug; RCT, randomizedcontrolled trial; RR, relative risk; SR, systematic review; SSRI, selective serotonin reuptake inhibitor.

significance. Because of the risk of gastrointestinal (GI) and renal AEs, ACP guidelines caution that clinicians recommend NSAIDs to be used at the lowest effective dose and shortest duration. ${ }^{15}$ Although these agents have analgesic benefits, a 2013 meta-analysis of 280 trials of NSAIDs versus placebo and 474 trials of one NSAID versus another NSAID found that all NSAIDs increased heart failure and upper GI complications. ${ }^{35}$

Four double-blind RCTs compared 12 to 14 weeks of treatment with the serotonin-norepinephrine reuptake inhibitor, duloxetine, versus placebo in 404 patients with nonradicular CLBP. ${ }^{36-39}$ In all 4 RCTs, key eligibility criteria were pain lasting $\geq 6$ months and average pain $\geq 4$ by Brief Pain Inventory (BPI). The oldest study found no statistically significant difference between once daily duloxetine $60 \mathrm{mg}$ versus placebo in the primary endpoint of reduction of pain severity assessed by the weekly BPI pain rating, with some statistically significant secondary endpoints. ${ }^{37}$ In contrast, the other 3 RCTs met their primary endpoints showing duloxetine to be superior to placebo in reducing pain intensity in patients with CLBP. $^{36,38,39}$

There are very few studies comparing nonopioid versus opioid therapies. The Minneapolis Veterans Affairs SPACE RCT found that over 12 months of treatment with opioids versus nonopioid therapy resulted in no significant difference $(p=0.58)$ in the primary endpoint of pain-related function, assessed with the BPI scale, and a significant difference $(p=0.03)$ favoring the nonopioid group in the secondary endpoint of pain intensity. The study included 240 adults with moderate-to-severe chronic back pain ( $65 \%$ of patients) or hip or knee osteoarthritis pain (35\%) lasting $\geq 6$ months despite analgesic use. ${ }^{40}$ Both interventions had 3 medication 
steps and were personalized based on individualized target goals. While single-opioid therapy was preferred, dual therapies could be considered based on patients' needs and preferences. Unfortunately, the study protocol used a pragmatic design and allowed use of nonpharmacologic therapies outside of study. Also, at the end of 1 year, less than $13 \%$ of patients in the opioid group received more than $50 \mathrm{MME}$ per day - perhaps too low a dose for severe CLBP. In the nonopioid group, up to $11 \%$ were concomitantly taking tramadol, which despite its pharmacologic mechanism was not considered as an opioid in this trial. Other limitations of this open-label study are the potential for bias because patients were not blinded to treatment and that the study population was skewed, with $87 \%$ of participants being men (and all were veterans). In addition, patients that required chronic opioid therapy were excluded from the study. Despite the limitations, this study supports the premise that certain patients may do well with nonopioid therapies, which should be first-line for the treatment of acute and chronic noncancer pain. Overall, data support that nonpharmacologic and nonopioid therapies should play a primary role in the multimodal approach to CLBP, recognizing that response to these treatments may be suboptimal.

\section{Opioid Therapy for CLBP}

The primary analgesic effects of opioids are mediated by binding to mu-opioid receptors (MORs), which are highly concentrated in regions of the brain and spinal cord that control pain perception and reward, as well as in the brain stem which explains the respiratory depression seen in opioid-related overdoses and deaths. ${ }^{41}$

Despite continuing efforts to maximize conservative treatments, opioids remain an option for patients with CLBP not sufficiently improved by other modalities. The indication stated in opioid product labels is for the management of pain severe enough to require opioid treatment and for which alternative treatment options are inadequate. Most medical boards, state guidelines, and even the CDC recognize that opioid analgesics remain an important treatment option in select refractory low-risk patients with appropriate and ongoing screening and monitoring strategies.

Unfortunately, since publication of the CDC guidelines, even stable patients on opioid treatment are being force tapered by prescribers due to perceived pressure by medical boards and payers, including the Centers for Medicare \& Medicaid Services. CDC guidelines recommend clinicians taper or reduce doses only when patient harm outweighs benefit. ${ }^{18} \mathrm{~A}$ recent call to action to prevent this forced tapering was published by international pain experts who noted that aggressive opioid tapering undermines patient care and outcomes, and increases patient distress. ${ }^{42}$ A recent New England Journal of Medicine perspective noted that some medical and health policies, purportedly derived from the CDC guidelines, include inflexible application of recommended dosage and duration threshold, and policies that encourage hard limits and abrupt tapering of opioid dosages. ${ }^{43}$ In response, prescribers have rapidly tapered or discontinued opioids, and even dismissed patients from their practices. These policies have in fact been inconsistent with, and often go beyond CDC's intended recommendations.

\section{Review of Opioid Therapy}

There are a multitude of published randomized-controlled trials (RCTs) that have evaluated the effectiveness and safety of the following opioids in patients with CLBP: hydrocodone bitartrate extended release (ER), ${ }^{44}$ hydrocodone bitartrate $E R,{ }^{45-47}$ hydromorphone $E R,{ }^{48}$ morphine sulfate $\mathrm{ER},{ }^{49,50}$ oxycodone ER, ${ }^{51}$ oxycodone/naloxone, ${ }^{52}$ oxymorphone ER, ${ }^{53-55}$ tramadol/acetaminophen ER, ${ }^{56-58}$ buprenorphine transdermal system, ${ }^{59-61}$ buccal buprenorphine, ${ }^{62}$ tapentadol ER, ${ }^{63,64}$ and tramadol ER. ${ }^{65}$ Data from these trials confirm that the opioids studied have at least shortterm (12-week) analgesic efficacy for chronic back pain. Most opioid clinical trials exclude patients with a history of substance abuse and mental health disorders - which account for a fair percentage of patients with chronic pain. ${ }^{66}$

A meta-analysis of 15 double-blind, placebo-controlled, enriched enrollment-randomized withdrawal (EERW) RCTs found that treatment with mu-agonist opioids for $\geq 12$ weeks was associated with statistically significant $(P<0.001)$ improvement in pain intensity, minor effects on physical function, and no effects on mental function in adults with chronic noncancer pain. ${ }^{67}$ The analyses revealed statistically significant differences for both $\geq 30 \%$ and $\geq 50 \%$ decreases in pain intensity from baseline (Figure 1). Eleven of the 15 included RCTs were in patients with CLBP. In 13 trials, patients were initially titrated to an individualized effective dose. This is a critically important fact to recognize that opioid effectiveness in the appropriate patient may be dependent upon titration to effective levels, not to an arbitrary MME maximum dose.

A systematic review and meta-analysis of 96 RCTs reported that high-quality evidence from a subset of 42 RCTs (with follow-up of at least 3 months) revealed 


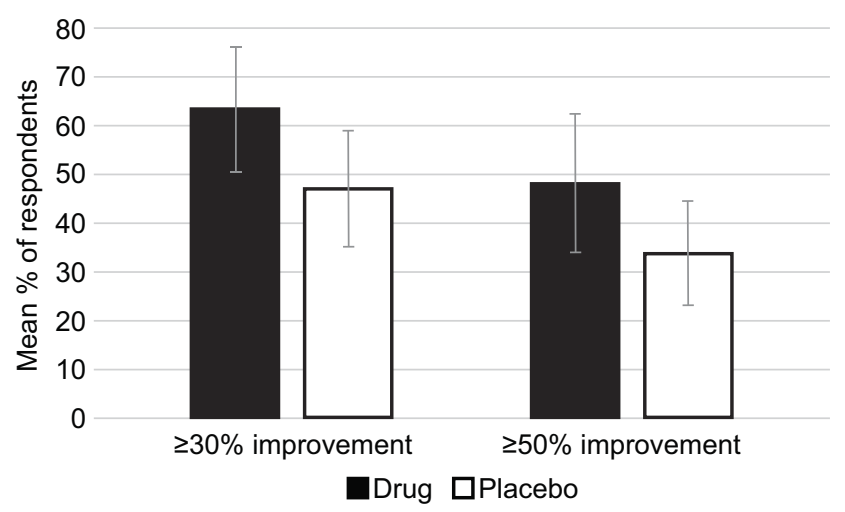

Figure I Efficacy of opioid versus placebo in chronic pain: Responder rates in a meta-analysis of enriched enrollment-randomized controlled trials [Figure adapted from Meske et al (20I8)]. ${ }^{67}$

a numerically small but statistically significant improvement in pain and physical functioning with opioid treatment versus both placebo and non-opioid analgesics in patients with chronic noncancer pain. ${ }^{68}$

Critics of chronic opioid therapy note that in addition to being of brief duration (generally, $\leq 3$ months), the RCTs have high dropout rates, and are performed in a selected "enriched" patient population. Most used an EERW design - whereby all enrolled patients enter an initial open-label phase to titrate the study drug to achieve individual efficacy, and then only the responders and those who tolerate the drug are randomized to the active and control groups. ${ }^{69}$ The US Food and Drug Administration (FDA) accepts studies with enriched designs for the sake of efficiency in the drug development process and with the caveat that labeling would reflect any limitations and concerns regarding the applicability of the clinical data to a wider unselected patient population. ${ }^{70}$ In 2014, an Initiative on Methods, Measurement, and Pain Assessment in Clinical Trials (IMMPACT) analysis noted that while there was insufficient evidence to support the assumption that EERW design increases the overall effect size (difference between the two groups), it might help identify treatments that would benefit only certain patient subpopulations. ${ }^{71}$ Studies comparing enriched and nonenriched clinical trials for chronic noncancer pain have found that while enriched designs does not seem to impact the pain-related efficacy results, they might underestimate the risk of AEs. ${ }^{72,73}$ In addition, a meta-analysis of 20 placebo-controlled RCTs of opioid analgesics for nonspecific LBP found that the use of enrichment designs was not associated with an exaggerated treatment effect. ${ }^{74}$ It found moderate-quality evidence that opioid analgesics reduce pain in the short term, but suggested that the effect is not likely to be "clinically important." Instead of using statistical significance, the authors converted pain and disability outcomes to a common 0 to 100 scale, with effects $>20$ points considered clinically important, a cutoff level that seems to be arbitrarily selected. The data were affected by high rates $(\geq 50 \%)$ of dropouts in half of the trials and no attempts were made to assess the long-term effects of opioids.

As others ${ }^{75,76}$ have critiqued, there are no high-quality studies with long-term data (defined as $>1$ year) on the safety and effectiveness of opioid treatment to reduce pain and improve function in patients with chronic pain. One reason for these limitations is that in order to gain FDA approval for analgesics with chronic pain indications, manufacturers are only required to do 12-week efficacy studies performed as double-blind RCTs. Not only would it be unethical to subject patients in pain to placebo for longer periods of time, enrollment and avoiding dropout in placebo studies for 1-year would be challenging for patients with active pain syndromes.

Despite limited high-quality data supporting long-term opioid use, clinical experience dictates, and guidelines recognize that opioid analgesics are an effective adjuvant for the treatment of refractory patients with moderate-to-severe CLBP. Clinicians need to weigh the analgesic benefit against the potential AEs including risk for opioid abuse, overdose, and other long-term effects. ${ }^{76}$

\section{Patient Selection}

Healthcare practitioners should recognize that opioids should not be used routinely as monotherapy, and instead should be added to other nonpharmacologic and primary pharmacologic therapies. Patient selection is critical to the safety and success of opioid therapy. A personal or family history of drug or alcohol abuse and psychiatric comorbidities represent the most notable risk factors. Available tools such as the Screener and Opioid Assessment for Patients with Pain questionnaire, ${ }^{77}$ the Opioid Risk Tool, ${ }^{78}$ and the Diagnosis, Intractability, Risk, Efficacy score ${ }^{79}$ are validated assessment tools that clinicians can utilize to stratify risk. In addition to careful patient selection, the actual choice of opioid molecule or formulation may be an important factor. Subtle but important pharmacological differences have been observed among the mu opioids; their potency, effectiveness, and adverse effects can vary unpredictably among patients. ${ }^{80}$

\section{Drug Selection}

Once eligible patients are identified, an opioid trial is recommended, which establishes if the patient is a responder to 
a select opioid and can tolerate the therapy. This may also help determine the best opioid drug to utilize via a process of opioid rotation, as pharmacologic and pharmacogenetic variables affect how a person responds to an individual opioid. With multiple opioid receptor and subtypes known, a particular patient may respond better to one opioid than to another. Hence, opioid rotation has the potential to maximize efficacy and decrease AEs. Given the growing list of opioid choices, matching the right patient to the right molecule may prove a clinical challenge. As advances in drug technology progress, drug selection has become even more complicated because clinicians have to choose from a variety of rapid, short and long-acting formulations both with and without abuse-deterrent properties. Although some ER opioid labels describe their use in opioid naïve patients, the CDC guidelines recommend starting with immediate-release (IR) opioids and using the lowest effective dose for the shortest possible duration. ${ }^{81}$

\section{Abuse-Deterrent Opioids}

As part of their efforts to address the opioid abuse epidemic, the US FDA has enacted policies to encourage manufacturers to develop innovative abuse-deterrent formulations (ADFs) that have the potential to make abuse of these products more difficult or less rewarding. ${ }^{82}$ The agency recognizes that abuse-deterrent opioids are not abuse- or addiction-proof, but are a step toward products that may help reduce abuse. ${ }^{83}$ Notably, currently marketed technologies do not effectively deter one of the most common forms of opioid abuse, swallowing the intact tablet or capsule. Because opioid medications must deliver the opioid to the patient, there may always be some potential for addiction and abuse, especially with non-ADF legacy opioid products. ${ }^{83}$

There are several strategies for developing opioid ADFs. ${ }^{41,84-86}$ The most common one is to create physicochemical barriers in opioid delivery systems that resist being crushed and extracted for snorting, smoking, or injecting. Another is to combine an opioid agonist with a sequestered antagonist that is released only if the formulation is tampered with. Other approaches may include combining opioids with aversive agents that trigger an $\mathrm{AE}$ if tampered or used at higher doses than indicated or formulating opioids as prodrugs that necessitate GI enzymatic activation for activity. As of now, there is no abuseproof opioid as most continue to have inherent likability, can be defeated with some advanced technical knowledge, and have no protection against oral over-consumption.

\section{Opioid-Like Molecules of the Future}

More than 72,000 Americans died from drug overdoses in 2017, including illicit drugs and prescription opioids - a 2-fold increase in the past decade. Approximately 49,000 of these deaths were related to opioids; the sharpest increase occurred in deaths related to fentanyl and fentanyl analogs (synthetic opioids) accounting for nearly 30,000 overdose deaths. ${ }^{87}$

These trends in morbidity and mortality support the need for effective analgesics that may diminish reward or deter abuse. There are a number of investigational opioidlike molecules, not all of which have been specifically studied in CLBP. The following are in development with no guarantee of ever meeting regulatory criteria of approval (Table 3).

\section{Slow-Entry Opioid}

NKTR-181 is a first-in-class new chemical entity with purported abuse-deterrent properties, unique from typical ADFs. It acts as a "slow-entry" mu-opioid agonist by decelerating passage through the blood-brain barrier into the central nervous system (CNS). The chemical structure of NKTR-181 comprises an opioid backbone modified by the addition of a bulky polyethylene glycol side chain designed to slow the rate of uptake in the CNS. In preclinical models, it has shown similar analgesic effects with lower abuse potential compared with oxycodone. ${ }^{88}$ The FDA has granted NKTR-181 Fast Track designation for the treatment of moderate to severe chronic pain and is pending review at an FDA Advisory Committee meeting.

NKTR-181 is the first analgesic opioid molecule to exhibit reduction in specific CNS-mediated side effects, like euphoria, through the strategic alteration of brain entry kinetics. Researchers have reported that the reinforcing effect of a drug is directly related to the rate of entry to the CNS. ${ }^{89}$ According to the manufacturer, there are no known chemical or physical methods to successfully increase the rate of CNS entry for abuse without inactivating the molecule. ${ }^{90}$

A human abuse potential (HAP) study at therapeutic doses demonstrated statistically significant lower abuse potential compared with $40 \mathrm{mg}$ oxycodone IR. ${ }^{90}$ These results have been replicated in another HAP study which compared NKTR-181 at the highest therapeutic dose (400 mg) and 2 supra-therapeutic doses $(600,1200 \mathrm{mg}$ ) versus 2 doses of oxycodone IR (40 and $60 \mathrm{mg}$ ). ${ }^{91,92}$ Compared with 40 and $60 \mathrm{mg}$ of oxycodone, the primary 
Table 3 Opioid-Like Molecules of the Future

\begin{tabular}{|l|l|l|l|}
\hline Class & Drugs & MOA & $\begin{array}{l}\text { Stage of Clinical } \\
\text { Development }\end{array}$ \\
\hline Slow-entry opioid & NKTR-18I & Mu-opioid agonist & Phase 3 \\
\hline $\begin{array}{l}\text { Opioid/ORL-I } \\
\text { combinations }\end{array}$ & Cebranopadol & ORL-I and opioid peptide agonist & Phase 2 \\
\hline Beta-arrestin sparing & $\begin{array}{l}\text { Oliceridine } \\
\text { (TRVI30) }\end{array}$ & Mu-opioid receptor agonist & Phase 3 \\
\hline KORA & CR845 & KORA & Phase 3 \\
\hline Enkephalin & PL37, PL2265 & Dual enkephalinase inhibitor & Phase I \\
\cline { 2 - 4 } & NM0127 & $\begin{array}{l}\text { Polymer nanoparticle encapsulating an enkephalin } \\
\text { substrate }\end{array}$ & Preclinical \\
\hline Endomorphin & CYT-I0I0 & Endomorphin-I analog & Phase I \\
\hline Opioid antagonist & Naltrexone & Antagonist of mu, delta, kappa opioid receptors & Phase I \\
\hline
\end{tabular}

Abbreviations: KORA, kappa-opioid receptor agonists; MOA, mechanism of action; ORI-I, opioid receptor-like receptor.

endpoint of mean Drug-Liking $\mathrm{E}_{\max }$ was significantly lower with NKTR-181 at the 400 and $600 \mathrm{mg}$ doses $(P<0.0001)$. At the NKTR-181 $1200 \mathrm{mg}$ dose there was a significant decrease versus $60 \mathrm{mg}$ oxycodone $(P=0.007)$ but not versus $40 \mathrm{mg}$ oxycodone $(P=0.515)$. Secondary endpoints and the treatment-emergent adverse event (TEAE) profile also favored NKTR-181 compared with oxycodone.

The Phase 3 SUMMIT-07 study compared 12 weeks of twice daily (BID) dosing of NKTR-181 (100 to $400 \mathrm{mg}$ ) versus placebo in adults with moderate to severe CLBP refractory to non-opioid analgesics. ${ }^{93}$ This study met its primary endpoint with a significantly lower mean change in weekly pain scores from baseline to week-12 $(P=0.002)$ versus placebo. Secondary endpoints that favored NKTR181 included percentage of patients with $30 \%$ and $50 \%$ improvement in pain, Patient Global Impression of Change, and 4 of 6 measures in the Medical Outcomes Study sleep scale. In the randomized phase, the most common AEs reported in the NKTR-181 versus placebo groups were constipation $(8.7 \%$ vs $3.0 \%)$, nausea $(10.4 \%$ vs $6.0 \%)$, somnolence $(2.6 \%$ vs $0.3 \%)$, headache ( $3.2 \%$ vs $4.7 \%)$, and vomiting ( $4.9 \%$ vs $1.7 \%)$.

A long-term safety and tolerability study of NKTR-181 in over 630 patients with moderate to severe CLBP or chronic noncancer pain (CNCP) reported that NKTR-181 at doses up to $600 \mathrm{mg}$ BID were generally well tolerated, and patients experienced low rates of opioid-related AEs. ${ }^{94}$ As speed of onset contributes to opioid misuse, a slow-entry agent into the CNS represents an incremental benefit to legacy mu-opioid analgesics.

\section{Mu Opioid/ORL-I Combinations}

Recognizing that CLBP often has both neuropathic and nociceptive components, researchers have developed a novel opioid compound that activates not only to the $\mathrm{mu}$ receptor but also to the more recently discovered opioid receptor-like receptor (ORL-1). Cebranopadol combines 2 different mechanism of action (MOA) providing both ORL-1 and opioid peptide receptor agonism. ${ }^{95}$ Preclinical data indicate that ORL-1 receptor activity may attenuate some of the MOP receptor-related effects, such as tolerance development, physical dependence, and addiction. Cebranopadol is formulated as an IR tablet with a long half-life of $\approx 24 \mathrm{hrs}$, lending itself to once daily administration. ${ }^{96}$

A Phase II, randomized, double-blind, placebo- and active-controlled trial evaluated cebranopadol in patients with moderate-to-severe CLBP with and without neuropathic pain. ${ }^{95}$ Patients were treated for 14 weeks with cebranopadol once daily (3 different dosages), tapentadol $200 \mathrm{mg}$ twice daily, or placebo. Cebranopadol and tapentadol showed statistically significant and clinically relevant improvements compared with placebo in the primary endpoint of change from baseline pain. In addition to analgesic benefits, cebranopadol had beneficial effects on sleep and functionality, and was generally well tolerated. 
Cebranopadol's MOA suggests that it may have lower potential for abuse compared with available legacy opioids. A 2019 randomized, double-blind crossover study evaluated the abuse potential of single doses of cebranopadol compared with hydromorphone-IR and placebo in nondependent recreational opioid users. ${ }^{96}$ From a drug-liking standpoint, lower doses of cebranopadol did not appear to differ from placebo; higher doses were similar to hydromorphone $8 \mathrm{mg}$. The investigators noted that the maximal drug-liking effect was delayed compared with hydromorphone (3 vs 1.5 hrs, respectively).

\section{Beta-Arrestin Sparing Opioids}

It has been postulated that opioid-related responsiveness, AEs, and tolerance may be related to opioid binding to G-protein coupled receptors, with subsequent binding (downstream signaling) of regulatory proteins called beta arrestins. ${ }^{97}$ Data suggest that inhibition of $\beta$-arrestin-2 function might lead to enhanced analgesic effectiveness of opioids like morphine, with a potential benefit of improved tolerability. ${ }^{98}$ Oliceridine (TRV130), a muopioid receptor agonist that activates $G$ protein signaling with little $\beta$-arrestin recruitment, is under investigation for the treatment of moderate-to-severe pain.

A Phase 2 study in acute pain following bunionectomy randomized 195 patients to 1 of 4 doses of oliceridine every $3 \mathrm{hrs}$, placebo, or morphine $4 \mathrm{mg}$ every $4 \mathrm{hrs} \mathrm{IV} .^{99}$ The 2 higher doses of oliceridine produced significantly greater pain relief compared with morphine $(P<0.005)$, with meaningful pain relief within 5 mins after the first dose. Oliceridine had no serious AEs, with similar tolerability to morphine. Of note, the dosing regimen was fixed and forced regardless of pain scores which may have contributed to the similarity in AEs. The sponsor received a complete response letter following an FDA Advisory Committee meeting in 2018, requesting additional clinical and nonclinical data.

Two phase 3 trials with oliceridine have been completed. The phase 3 APOLLO-1 study reported statistically improved pain relief compared with placebo in patients with moderate-to-severe acute post-bunionectomy surgical pain and noted that fewer patients receiving oliceridine discontinued treatment due to an $\mathrm{AE}$ than patients receiving morphine. ${ }^{100}$ The other phase 3 study (APOLLO-2) found that 2 doses of oliceridine were non-inferior in the treatment of moderate-to-severe acute pain following abdominoplasty and was associated with less nausea and vomiting compared with morphine. ${ }^{101}$ Both phase 3 studies concluded that oliceridine has a favorable safety and tolerability profile with regard to respiratory and GI AEs compared with morphine. These results demonstrated that G-protein-biased mu receptor activation may be a promising target for development of novel opioid analgesics.

\section{Kappa-Opioid Receptor Agonists (KORA)}

Although conventional opioids act predominantly on the mu receptor, the kappa and delta-opioid receptors may be viable targets for analgesic compounds. To avoid undesirable CNS and mu opioid-mediated AEs, there has been an effort to develop opioids which activate peripheral kappaopioid receptors present on sensory nerves, immune cells, and the dorsal root ganglion (DRG). Such compounds, peripheral kappa-opioid receptor agonists (KORAs), are thought to have the potential to provide pain relief without producing significant CNS and mu-opioid mediated side effects. CR845 is a KORA with a large hydrophilic structure intended to decrease its ability to penetrate the bloodbrain barrier while maintaining its effect on peripheral kappa-opioid receptors. ${ }^{102}$ A phase 2 study demonstrated that CR845 resulted in reduced pain intensity with lower incidence of nausea and vomiting versus placebo in patients after bunionectomy. ${ }^{103}$ In a June 2018 press release, ${ }^{104}$ the manufacturer announced positive results in a phase $2 / 3$ clinical trial of intravenous CR845 in patients undergoing abdominal surgery. These results have yet to be published. This class of peripherally acting opioid analgesics represents an important advance as they are not expected to produce significant euphoria or respiratory depression and we await further data to support their clinical utility in pain management. Kappa-opioid agonism inhibits itching in animals and humans; therefore, these compounds are also being studied in pursuit of an indication for refractory pruritus. ${ }^{105,106}$

\section{Enkephalins}

The endogenous opioid system is involved in key physiological functions such as pain and mood control. Exogenous opioid agonists such as morphine indiscriminately overstimulate all central and peripheral opioid receptors and may cause AEs such as constipation, respiratory depression, tolerance or dependence. In contrast, endogenous chemicals appear to activate only a limited number of structures involved in pain control, mostly in areas where the noxious stimulus takes place. ${ }^{107}$ The delta-opioid receptor is 
modulated by endogenous enkephalins, which have been studied in the past but not developed as analgesic drugs. Enkephalin agonists, or agents which inhibit its metabolism, may augment enkephalin-mediated analgesia while minimizing typical mu-opioid side effects. Potential means of augmenting enkephalin activation includes increasing the concentration and half-life by inhibiting two of the enzymes responsible for degradation (enkephalinases) or by administering exogenous enkephalin like agents. A novel class of degradation inhibitors known as dual enkephalinase (DENK) inhibitors are capable of inhibiting both enkephalinases, thereby increasing concentrations of enkephalins available to promote analgesia. ${ }^{108}$ A preliminary report suggests that the leading DENK inhibitors, PL265 and PL37, are devoid of any abuse potential even at high doses and after repeated administration, while providing similar levels of pain relief to opiates without their side-effects. ${ }^{109}$

Another way of increasing enkephalin exposure is via systemic or CNS administration of exogenous enkephalin, which has been a challenge due to its rapid enzymatic degradation and poor brain permeation. Although early in development, it has been shown in animals that polymer nanoparticles encapsulating an enkephalin substrate (leucine5-enkephalin hydrochloride [LENK]) are able to penetrate into the brain via the intranasal route. ${ }^{110}$ Animals dosed with LENK nanoparticles (NM0127) showed a strong anti-nociceptive response in multiple assays of evoked and ongoing pain. Animals did not develop tolerance to the anti-hyperalgesic activity of NM0127 which also remained active in morphine tolerant animals. Hence, early evidence suggests that targeting endogenous deltaopioid receptor agonists has the potential to improve analgesic efficacy, tolerability, and safety.

\section{Endomorphins}

The discovery of endomorphins (EMs), another unique group of endogenous opioid peptides, provides the potential to dissociate analgesia from opioid-related adverse events. Endomorphin-1 and -2 are endogenous opioid peptides highly selective for mu-opioid receptors that exhibit potent analgesia with reduced side effects compared with morphine in acute and neuropathic pain studies. ${ }^{111}$ CYT-1010 is an analog of endomorphin-1 purported to have greater analgesic potency than morphine and reduced abuse potential; in an unpublished initial Phase 1 clinical study, CYT-1010 showed significant analgesia with no respiratory depression. ${ }^{112}$ In a February 2019 press release, ${ }^{113}$ the manufacturer announced receipt of FDA authorization to proceed with a phase 1a/2a study. Endomorphins are early in development and require further evaluation but may prove to be a promising alternative to conventional opioids.

\section{Opioid Antagonists}

Naltrexone is a long-acting, potent, competitive, nonselective opioid antagonist at all 3 major opioid receptors. ${ }^{114,115}$ Naltrexone is similar to the opioid antagonist naloxone with greater oral bioavailability and a longer half-life. ${ }^{116}$ Initially available in an oral formulation, a depo intramuscular formulation has been approved to treat alcohol dependence and prevent relapse to opioid dependence after opioid detoxification. ${ }^{117}$ Oral doses used in the treatment of opioid use disorders are typically around $50 \mathrm{mg}$. In recent years, evidence has emerged that low-dose naltrexone (LDN) has benefits for pain and autoimmune disorders. ${ }^{118}$ Pilot trials of LDN in Crohn's disease, ${ }^{119}$ multiple sclerosis, ${ }^{120}$ cancerrelated pain, ${ }^{121}$ and fibromyalgia ${ }^{122}$ have been conducted.

LDN also has an antagonist effect on certain nonopioid receptors including those found in microglia. ${ }^{123}$ It is via the non-opioid antagonist path that LDN is thought to exert its modulation of both peripheral and central inflammatory mediators, including TNF-alpha, IL-6, glial cells, and others. ${ }^{118,124}$

Although no large-scale, controlled trials of naltrexone in CLBP have been conducted (to our knowledge), case series/reports of the benefits for back pain have been noted. $^{125}$ It remains to be seen whether the efficacy of LDN will be established in controlled clinical trials. Nevertheless, there is compelling evidence for use of this agent — which lacks significant opioid-like side effects - to treat refractory pain of multiple etiologies.

\section{Outlook and Conclusions}

The pathophysiology associated with CLBP is complex, and treatment entails a multimodal approach often requiring opioid analgesics when pain remains refractory. Unfortunately, many patients with CLBP do not respond or have no access to conservative and complementary therapies, for which evidence of effectiveness is moderate at best. As a last resort, clinicians are faced with the daunting task of balancing the safety and effectiveness of opioid analgesics.

Newer pharmacologic agents are in developmentincluding opioids and other drugs with novel MOAs - that should improve our ability to treat pain syndromes like refractory CLBP. First-generation abuse-deterrent opioid 
formulations have incremental benefits over legacy products, but developing new classes of opioid receptor agonists that enter the CNS slowly, use biased signaling, and/or target novel sites to produce analgesia has the potential to improve safety, tolerability, and abuse liability.

\section{Acknowledgments}

Phillips Gilmore Oncology Communications provided medical editing and writing support, funded by Nektar Therapeutics.

\section{Disclosure}

JG in the past year has served as a consultant for Averitas, Hisumitsu, Mallinckrodt, Nektar, Purdue and Quest Diagnostics; as an advisory board member for AcelRx Pharmaceuticals and GlaxoSmithKline; and as a consultant and part of a speaker's bureau for BioDelivery Sciences International, DSI, Salix Pharmaceuticals, and Scilex Pharmaceuticals. AGK is a speaker for Purdue Pharma. The authors report no other conflicts of interest in this work.

\section{References}

1. GBD. Global, regional, and national incidence, prevalence, and years lived with disability for 310 diseases and injuries, 1990-2015: a systematic analysis for the global burden of disease study 2015. Lancet. 2016;388(10053):1545-1602. doi:10.1016/ S0140-6736(16)31678-6

2. NCHS. Health, United States, 2016: with chartbook on long-term trends in health. 2016;194-196. Available from: https://www.cdc. gov/nchs/data/hus/hus16.pdf

3. Chou R, Shekelle P. Will this patient develop persistent disabling low back pain? JAMA. 2010;303(13):1295-1302. doi:10.1001/ jama.2010.344

4. Herndon CM, Zoberi KS, Gardner BJ. Common questions about chronic low back pain. Am Fam Physician. 2015;91(10):708-714.

5. Shmagel A, Foley R, Ibrahim H. Epidemiology of chronic low back pain in US adults: data from the 2009-2010 National Health and Nutrition Examination Survey. Arthritis Care Res (Hoboken). 2016;68(11):1688-1694. doi:10.1002/acr.v68.11

6. Dahlhamer J, Lucas J, Zelaya C, et al. Prevalence of chronic pain and high-impact chronic pain among adults - United States, 2016. MMWR Morb Mortal Wkly Rep. 2018;67(36):1001-1006. doi:10.15585/mmwr.mm6736a2

7. Gore M, Sadosky A, Stacey BR, Tai KS, Leslie D. The burden of chronic low back pain: clinical comorbidities, treatment patterns, and health care costs in usual care settings. Spine (Phila Pa 1976). 2012;37(11):E668-677. doi:10.1097/BRS.0b013e318241e5de

8. Mokdad AH, Ballestros K, Echko M, et al. The state of US health, 1990-2016: burden of diseases, injuries, and risk factors among US states. JAMA. 2018;319(14):1444-1472. doi:10.1001/jama.2018.0158

9. Hartvigsen J, Hancock MJ, Kongsted A, et al. What low back pain is and why we need to pay attention. Lancet. 2018;391 (10137):2356-2367. doi:10.1016/S0140-6736(18)30480-X

10. Boden SD, Davis DO, Dina TS, Patronas NJ, Wiesel SW. Abnormal magnetic-resonance scans of the lumbar spine in asymptomatic subjects. a prospective investigation. J Bone Joint Surg Am. 1990;72(3):403-408. doi:10.2106/00004623-199072030-00013
11. Aprill C, Bogduk N. High-intensity zone: a diagnostic sign of painful lumbar disc on magnetic resonance imaging. $\mathrm{Br} J$ Radiol. 1992;65(773):361-369. doi:10.1259/0007-1285-65-773-361

12. Kean Chen C, Nizar AJ. Prevalence of piriformis syndrome in chronic low back pain patients. A clinical diagnosis with modified FAIR test. Pain Pract. 2013;13(4):276-281. doi:10.1111/papr.2013.13.issue-4

13. Manniche C, Jordan A. 10 years of research: from ignoring Modic changes to considerations regarding treatment and prevention of low-grade disc infections. Future Sci OA. 2016;2(2):Fso117. doi:10.4155/fsoa-2016-0017

14. Brinjikji W, Diehn FE, Jarvik JG, et al. MRI findings of disc degeneration are more prevalent in adults with low back pain than in asymptomatic controls: a systematic review and meta-analysis. AJNR Am J Neuroradiol. 2015;36(12):2394-2399. doi:10.3174/ ajnr.A4498

15. Qaseem A, Wilt TJ, McLean RM, Forciea MA. Noninvasive treatments for acute, subacute, and chronic low back pain: a clinical practice guideline from the american college of physicians. Ann Intern Med. 2017;166(7):514-530. doi:10.7326/M16-2367

16. Dowell D, Haegerich TM. Using the CDC guideline and tools for opioid prescribing in patients with chronic pain. Am Fam Physician. 2016;93(12):970-972.

17. Dowell D, Haegerich TM, Chou R. CDC guideline for prescribing opioids for chronic pain - United States, 2016. MMWR Recomm Rep. 2016;65(1):1-49. doi:10.15585/mmwr.rr6501e1

18. Dowell D, Haegerich TM, Chou R. CDC guideline for prescribing opioids for chronic pain-United States, 2016. JAMA. 2016;315 (15):1624-1645. doi:10.1001/jama.2016.1464

19. Manchikanti L, Kaye AM, Knezevic NN, et al. Responsible, safe, and effective prescription of opioids for chronic non-cancer pain: american Society of Interventional Pain Physicians (ASIPP) guidelines. Pain Physician. 2017;20(2s):S3-S92. doi:10.36076/ ppj.2017.s92

20. Manchikanti L, Buenaventura RM, Manchikanti KN, et al. Effectiveness of therapeutic lumbar transforaminal epidural steroid injections in managing lumbar spinal pain. Pain Physician. 2012;15 (3):E199-245.

21. Sharma AK, Vorobeychik Y, Wasserman R, et al. The effectiveness and risks of fluoroscopically guided lumbar interlaminar epidural steroid injections: a systematic review with comprehensive analysis of the published data. Pain Med. 2017;18(2):239-251. doi:10.1093/ $\mathrm{pm} / \mathrm{pnw} 131$

22. Thomson S. Failed back surgery syndrome - definition, epidemiology and demographics. Br J Pain. 2013;7(1):56-59. doi:10.1177/ 2049463713479096

23. Chou R, Deyo R, Friedly J, et al. Nonpharmacologic therapies for low back pain: a systematic review for an American college of physicians clinical practice guideline. Ann Intern Med. 2017;166 (7):493-505. doi:10.7326/M16-2459

24. Skelly AC, Chou R, Dettori JR, et al. Noninvasive nonpharmacological treatment for chronic pain: a systematic review. Comparative Effectiveness Review No. 209. (Prepared by the Pacific Northwest Evidence-based Practice Center under Contract No. 290-2015-000009-I). AHRQ Publication No 18-EHC013-EF. 2018. Available from: https://effectivehealthcare.ahrq.gov/topics/ nonpharma-treatment-pain/research-2018. Accessed July 11, 2018.

25. Wieland LS, Skoetz N, Pilkington K, Vempati R, D'adamo CR, Berman BM. Yoga treatment for chronic non-specific low back pain. Cochrane Database Syst Rev. 2017;1:Cd010671.

26. Yamato TP, Maher CG, Saragiotto BT, et al. Pilates for low back pain. Cochrane Database Syst Rev. 2015;7:Cd010265.

27. Cherkin DC, Sherman KJ, Balderson BH, et al. Effect of mindfulness-based stress reduction vs cognitive behavioral therapy or usual care on back pain and functional limitations in adults with chronic low back pain: a randomized clinical trial. JAMA. 2016;315 (12):1240-1249. doi:10.1001/jama.2016.2323 
28. Coulter ID, Crawford C, Hurwitz EL, et al. Manipulation and mobilization for treating chronic low back pain: a systematic review and meta-analysis. Spine J. 2018;18(5):866-879. doi:10.1016/j.spinee. 2018.01.013

29. Sun E, Moshfegh J, Rishel CA, Cook CE, Goode AP, George SZ. Association of early physical therapy with long-term opioid use among opioid-naive patients with musculoskeletal pain. JAMA Netw Open. 2018;1(8):e185909. doi:10.1001/jamanetworkopen.2018.5909

30. van Middelkoop M, Rubinstein SM, Kuijpers T, et al. A systematic review on the effectiveness of physical and rehabilitation interventions for chronic non-specific low back pain. Eur Spine J. 2011;20 (1):19-39. doi:10.1007/s00586-010-1518-3

31. Cuenca-martinez F, Cortes-amador S, Espi-lopez GV. Effectiveness of classic physical therapy proposals for chronic non-specific low back pain: a literature review. Phys Ther Res. 2018;21(1):16-22. doi:10.1298/ptr.E9937

32. Chou R, Deyo R, Friedly J, et al. Systemic pharmacologic therapies for low back pain: a systematic review for an American college of physicians clinical practice guideline. Ann Intern Med. 2017;166 (7):480-492. doi:10.7326/M16-2458

33. Enthoven WT, Roelofs PD, Deyo RA, van Tulder MW, Koes BW. Non-steroidal anti-inflammatory drugs for chronic low back pain. Cochrane Database Syst Rev. 2016;2:Cd012087. doi:10.1002/ 14651858.CD004158.pub3

34. Enthoven WT, Roelofs PD, Koes BW. NSAIDs for chronic low back pain. JAMA. 2017;317(22):2327-2328. doi:10.1001/ jama.2017.4571

35. Bhala N, Emberson J, Merhi A, et al. Vascular and upper gastrointestinal effects of non-steroidal anti-inflammatory drugs: meta-analyses of individual participant data from randomised trials. Lancet. 2013;382(9894):769-779.

36. Skljarevski V, Desaiah D, Liu-Seifert H, et al. Efficacy and safety of duloxetine in patients with chronic low back pain. Spine (Phila $\mathrm{Pa}$ 1976). 2010;35(13):E578-585. doi:10.1097/BRS.0b013e3181d3cef6

37. Skljarevski V, Ossanna M, Liu-seifert $\mathrm{H}$, et al. A double-blind, randomized trial of duloxetine versus placebo in the management of chronic low back pain. Eur J Neurol. 2009;16(9):1041-1048. doi:10.1111/ene.2009.16.issue-9

38. Skljarevski V, Zhang S, Desaiah D, et al. Duloxetine versus placebo in patients with chronic low back pain: a 12-week, fixed-dose, randomized, double-blind trial. J Pain. 2010;11(12):1282-1290. doi:10.1016/j.jpain.2010.03.002

39. Konno S, Oda N, Ochiai T, Alev L. Randomized, double-blind, placebo-controlled Phase III trial of duloxetine monotherapy in japanese patients with chronic low back pain. Spine (Phila Pa 1976). 2016;41(22):1709-1717. doi:10.1097/BRS.0000000000001707

40. Krebs EE, Gravely A, Nugent S, et al. Effect of opioid vs nonopioid medications on pain-related function in patients with chronic back pain or hip or knee osteoarthritis pain: the SPACE randomized clinical trial. JAMA. 2018;319(9):872-882. doi:10.1001/jama.2018.0899

41. Volkow ND, McLellan AT. Opioid abuse in chronic pain-misconceptions and mitigation strategies. $N$ Engl J Med. 2016;374 (13):1253-1263. doi:10.1056/NEJMra1507771

42. Darnall BD, Juurlink D, Kerns RD, et al. International stakeholder community of pain experts and leaders call for an urgent action on forced opioid tapering. Pain Med. 2019;20(3):429-433. doi:10.1093/pm/pny228

43. Dowell D, Haegerich T, Chou R. No shortcuts to safer opioid prescribing. N Engl J Med. 2019;380(24):2285-2287. doi:10.1056/ NEJMp1904190

44. Wen W, Sitar S, Lynch SY, He E, Ripa SR. A multicenter, randomized, double-blind, placebo-controlled trial to assess the efficacy and safety of single-entity, once-daily hydrocodone tablets in patients with uncontrolled moderate to severe chronic low back pain. Expert Opin Pharmacother. 2015;16(11):1593-1606. doi:10.1517/14656566.2015. 1060221
45. Rauck RL, Nalamachu S, Wild JE, et al. Single-entity hydrocodone extended-release capsules in opioid-tolerant subjects with moderate-tosevere chronic low back pain: a randomized double-blind, placebo-controlled study. Pain Med. 2014;15(6):975-985. doi:10. 1111/pme. 12377

46. Hale ME, Laudadio C, Yang R, Narayana A, Malamut R. Efficacy and tolerability of a hydrocodone extended-release tablet formulated with abuse-deterrence technology for the treatment of moderate-to-severe chronic pain in patients with osteoarthritis or low back pain. J Pain Res. 2015;8:623-636. doi:10.2147/JPR

47. Hale ME, Zimmerman TR, Eyal E, Malamut R. Efficacy and safety of a hydrocodone extended-release tablet formulated with abuse-deterrence technology in patients with moderate-to-severe chronic low back pain. J Opioid Manag. 2015;11(6):507-518. doi:10.5055/jom.2015.0304

48. Hale M, Khan A, Kutch M, Li S. Once-daily OROS hydromorphone ER compared with placebo in opioid-tolerant patients with chronic low back pain. Curr Med Res Opin. 2010;26 (6):1505-1518. doi:10.1185/03007995.2010.484723

49. Rauck RL, Bookbinder SA, Bunker TR, et al. The ACTION study: a randomized, open-label, multicenter trial comparing once-a-day extended-release morphine sulfate capsules (AVINZA) to twice-a-day controlled-release oxycodone hydrochloride tablets (OxyContin) for the treatment of chronic, moderate to severe low back pain. $J$ Opioid Manag. 2006;2(3):155-166. doi:10.5055/jom.2006.0025

50. Rauck RL, Bookbinder SA, Bunker TR, et al. A randomized, open-label study of once-a-day AVINZA (morphine sulfate extended-release capsules) versus twice-a-day OxyContin (oxycodone hydrochloride controlled-release tablets) for chronic low back pain: the extension phase of the ACTION trial. $J$ Opioid Manag. 2006;2(6):325-328, 331-323. doi:10.5055/jom.2006.0048

51. Katz N, Kopecky EA, O'connor M, Brown RH, Fleming AB. A phase 3, multicenter, randomized, double-blind, placebo-controlled, safety, tolerability, and efficacy study of Xtampza ER in patients with moderate-to-severe chronic low back pain. Pain. 2015;156 (12):2458-2467. doi:10.1097/j.pain.0000000000000315

52. Ueberall MA, Mueller-schwefe GH. Safety and efficacy of oxycodone/naloxone vs. oxycodone vs. morphine for the treatment of chronic low back pain: results of a 12 week prospective, randomized, open-label blinded endpoint streamlined study with prolonged-release preparations. Curr Med Res Opin. 2015;31 (7):1413-1429. doi:10.1185/03007995.2015.1047747

53. Katz N, Rauck $\mathrm{R}$, Ahdieh $\mathrm{H}$, et al. A 12-week, randomized, placebo-controlled trial assessing the safety and efficacy of oxymorphone extended release for opioid-naive patients with chronic low back pain. Curr Med Res Opin. 2007;23(1):117-128. doi:10.1185/030079906X162692

54. Hale ME, Ahdieh H, Ma T, Rauck R. Efficacy and safety of OPANA ER (oxymorphone extended release) for relief of moderate to severe chronic low back pain in opioid-experienced patients: a 12-week, randomized, double-blind, placebo-controlled study. J Pain. 2007;8(2):175-184. doi:10.1016/j.jpain.2006.09.011

55. Hale ME, Dvergsten C, Gimbel J. Efficacy and safety of oxymorphone extended release in chronic low back pain: results of a randomized, double-blind, placebo- and active-controlled phase III study. J Pain. 2005;6(1):21-28. doi:10.1016/j.jpain.2004.09.005

56. Lee JH, Lee CS. A randomized, double-blind, placebo-controlled, parallel-group study to evaluate the efficacy and safety of the extended-release tramadol hydrochloride/acetaminophen fixed-dose combination tablet for the treatment of chronic low back pain. Clin Ther. 2013;35(11):1830-1840. doi:10.1016/j.clinthera.2013.09.017

57. Peloso PM, Fortin L, Beaulieu A, Kamin M, Rosenthal N. Analgesic efficacy and safety of tramadol/acetaminophen combination tablets (Ultracet) in treatment of chronic low back pain: a multicenter, outpatient, randomized, double blind, placebo controlled trial. J Rheumatol. 2004;31(12):2454-2463. 
58. Ruoff GE, Rosenthal N, Jordan D, Karim R, Kamin M. Tramadol/ acetaminophen combination tablets for the treatment of chronic lower back pain: a multicenter, randomized, double-blind, placebo-controlled outpatient study. Clin Ther. 2003;25(4):1123-1141. doi:10.1016/ S0149-2918(03)80071-1

59. Steiner D, Munera C, Hale M, Ripa S, Landau C. Efficacy and safety of buprenorphine transdermal system (BTDS) for chronic moderate to severe low back pain: a randomized, double-blind study. J Pain. 2011;12(11):1163-1173. doi:10.1016/j.jpain.2011.06.003

60. Steiner DJ, Sitar S, Wen W, et al. Efficacy and safety of the seven-day buprenorphine transdermal system in opioid-naive patients with moderate to severe chronic low back pain: an enriched, randomized, double-blind, placebo-controlled study. J Pain Symptom Manage. 2011;42(6):903-917. doi:10.1016/j.jpainsymman.2011.04.006

61. Gordon A, Callaghan D, Spink D, et al. Buprenorphine transdermal system in adults with chronic low back pain: a randomized, double-blind, placebo-controlled crossover study, followed by an open-label extension phase. Clin Ther. 2010;32(5):844-860. doi:10.1016/j.clinthera.2010.04.018

62. Rauck RL, Potts J, Xiang Q, Tzanis E, Finn A. Efficacy and tolerability of buccal buprenorphine in opioid-naive patients with moderate to severe chronic low back pain. Postgrad Med. 2016;128 (1):1-11. doi:10.1080/00325481.2016.1128307

63. Buynak R, Rappaport SA, Rod K, et al. Long-term safety and efficacy of tapentadol extended release following up to 2 years of treatment in patients with moderate to severe, chronic pain: results of an open-label extension trial. Clin Ther. 2015;37(11):2420-2438. doi:10.1016/j.clinthera.2015.08.014

64. Buynak R, Shapiro DY, Okamoto A, et al. Efficacy and safety of tapentadol extended release for the management of chronic low back pain: results of a prospective, randomized, double-blind, placebo- and active-controlled Phase III study. Expert Opin Pharmacother. 2010;11(11):1787-1804. doi:10.1517/14656566. 2010.497720

65. Vorsanger GJ, Xiang J, Gana TJ, Pascual ML, Fleming RR. Extended-release tramadol (tramadol ER) in the treatment of chronic low back pain. J Opioid Manag. 2008;4(2):87-97. doi:10.5055/jom.2008.0013

66. Bair MJ, Robinson RL, Katon W, Kroenke K. Depression and pain comorbidity: a literature review. Arch Intern Med. 2003;163 (20):2433-2445. doi:10.1001/archinte.163.20.2433

67. Meske DS, Lawal OD, Elder H, Langberg V, Paillard F, Katz N. Efficacy of opioids versus placebo in chronic pain: a systematic review and meta-analysis of enriched enrollment randomized withdrawal trials. J Pain Res. 2018;11:923-934. doi: $10.2147 / \mathrm{JPR}$

68. Busse JW, Wang L, Kamaleldin M, et al. Opioids for chronic noncancer pain: a systematic review and meta-analysis. JAMA. 2018;320(23):2448-2460. doi:10.1001/jama.2018.18472

69. Campbell J, King NB. "Unsettling circularity": clinical trial enrichment and the evidentiary politics of chronic pain. BioSocieties. 2017;12(2):191-216. doi:10.1057/biosoc.2016.7

70. FDA. U.S. Department of Health and Human Services. Food and Drug Administration. Guidance for industry: enrichment strategies for clinical trials to support approval of human drugs and biological products. 2012. Available from: https://www.fda.gov/downloads/ Drugs/GuidanceComplianceRegulatoryInformation/Guidances/ UCM332181.pdf. Accessed July 31, 2018.

71. Gewandter JS, Dworkin RH, Turk DC, et al. Research designs for proof-of-concept chronic pain clinical trials: IMMPACT recommendations. Pain. 2014;155(9):1683-1695. doi:10.1016/j. pain.2014.05.025

72. Yamato TP, Maher CG, Saragiotto BT, et al. Comparison of effect sizes between enriched and nonenriched trials of analgesics for chronic musculoskeletal pain: a systematic review. $\mathrm{Br} \mathrm{J}$ Clin Pharmacol. 2017;83(11):2347-2355. doi:10.1111/bcp.v83.11
73. Furlan A, Chaparro LE, Irvin E, Mailis-gagnon A. A comparison between enriched and nonenriched enrollment randomized withdrawal trials of opioids for chronic noncancer pain. Pain Res Manag. 2011;16(5):337-351. doi:10.1155/2011/465281

74. Abdel Shaheed C, Maher CG, Williams KA, Day R, McLachlan AJ. Efficacy, tolerability, and dose-dependent effects of opioid analgesics for low back pain: a systematic review and meta-analysis. JAMA Intern Med. 2016;176(7):958-968. doi:10.1001/jamainternmed.2016.1251

75. Jones MR, Viswanath O, Peck J, Kaye AD, Gill JS, Simopoulos TT. A brief history of the opioid epidemic and strategies for pain medicine. Pain Ther. 2018;7(1):13-21. doi:10.1007/ s40122-018-0097-6

76. Chou R, Turner JA, Devine EB, et al. The effectiveness and risks of long-term opioid therapy for chronic pain: a systematic review for a National Institutes of Health Pathways to Prevention Workshop. Ann Intern Med. 2015;162(4):276-286. doi:10.7326/M14-2559

77. Butler SF, Fernandez K, Benoit C, Budman SH, Jamison RN. Validation of the revised Screener and Opioid Assessment for Patients with Pain (SOAPP-R). J Pain. 2008;9(4):360-372. doi:10.1016/j.jpain.2007.11.014

78. Webster LR, Webster RM. Predicting aberrant behaviors in opioid-treated patients: preliminary validation of the opioid risk tool. Pain Med. 2005;6(6):432-442. doi:10.1111/j.15264637.2005.00072.x

79. Belgrade MJ, Schamber CD, Lindgren BR. The DIRE score: predicting outcomes of opioid prescribing for chronic pain. J Pain. 2006;7(9):671-681. doi:10.1016/j.jpain.2006.03.001

80. Pasternak GW. Molecular insights into mu opioid pharmacology: from the clinic to the bench. Clin J Pain. 2010;26(Suppl 10):S3-9. doi:10.1097/AJP.0b013e3181c49d2e

81. Centers For Disease C. Prevention Public Health Service USDOH, Human S. Guideline for prescribing opioids for chronic pain. $J$ Pain Palliat Care Pharmacother. 2016;30(2):138-140. doi:10.3109/15360288.2016.1173761

82. FDA. Statement from FDA Commissioner Scott Gottlieb, M.D., on agency's efforts to encourage the development of and broaden access to generic versions of opioid analgesics that are formulated to deter abuse. 2018. Available from: https://www.fda.gov/ NewsEvents/Newsroom/PressAnnouncements/ucm614110.htm. Accessed September 18, 2018.

83. FDA. Abuse-deterrent opioid analgesics. 2018. Available from: https:// www.fda.gov/Drugs/DrugSafety/PostmarketDrugSafetyInfor mationforPatientsandProviders/ucm600788.htm. Accessed October 10, 2018.

84. Becker WC, Fiellin DA. Abuse-deterrent opioid formulations putting the potential benefits into perspective. $N$ Engl J Med. 2017;376(22):2103-2105. doi:10.1056/NEJMp1701553

85. Lee YH, Brown DL, Chen HY. Current impact and application of abuse-deterrent opioid formulations in clinical practice. Pain Physician. 2017;20(7):E1003-E1023.

86. Hale ME, Moe D, Bond M, Gasior M, Malamut R. Abuse-deterrent formulations of prescription opioid analgesics in the management of chronic noncancer pain. Pain Manag. 2016;6(5):497-508. doi:10.2217/pmt-2015-0005

87. NIDA. National institute of drug abuse: overdose death rates. 2018. Available from: https://www.drugabuse.gov/related-topics/trendsstatistics/overdose-death-rates. Accessed January 25, 2019.

88. Miyazaki T, Choi IY, Rubas W, et al. NKTR-181: a novel mu-opioid analgesic with inherently low abuse potential. $J$ Pharmacol Exp Ther. 2017;363(1):104-113. doi:10.1124/ jpet.117.243030

89. Comer SD, Ashworth JB, Sullivan MA, Vosburg SK, Saccone PA, Foltin RW. Relationship between rate of infusion and reinforcing strength of oxycodone in humans. J Opioid Manag. 2009;5 (4):203-212. doi:10.5055/jom.2009.0022 
90. Webster L, Henningfield J, Buchhalter AR, et al. Human abuse potential of the new opioid analgesic molecule NKTR-181 compared with oxycodone. Pain Med. 2018;19(2):307-318. doi: $10.1093 / \mathrm{pm} / \mathrm{pnw} 344$

91. Ge XS, Henningfield J, Siddhanti S, et al. Human abuse potential of oral NKTR-181 in recreational opioid users: a randomized, double-blind, crossover study. Pain Med. Submitted. 2018.

92. Ge XS, Lu L, Jobes J, et al. Abuse potential of NKTR-181 in recreational opioid users: results from a randomized, double-blind crossover oral study. Paper presented at: American College of Neuropsychopharmacology 56th Annual Meeting2017; Palm Springs, CA.

93. Markman J, Gudin J, Rauck R, et al. SUMMIT-07: a randomized trial of NKTR-181, a new molecular entity, full mu-opioid receptor agonist for chronic low-back pain. Pain. 2019;160(6):1374-1382. doi:10.1097/j.pain.0000000000001517

94. Gudin J, Rauck R, Argoff C, et al. Long-term safety and tolerability of NKTR-181 in patients with moderate to severe chronic low back pain or chronic noncancer pain: a Phase 3 multicenter, open-label, 52-week study (SUMMIT-08 LTS). Pain Med. 2019. doi:10.1093/ pm/pnz169

95. Christoph A, Eerdekens MH, Kok M, Volkers G, Freynhagen R. Cebranopadol, a novel first-in-class analgesic drug candidate: first experience in patients with chronic low back pain in a randomized clinical trial. Pain. 2017;158(9):1813-1824. doi:10.1097/j.pain.000 0000000000986

96. Gohler K, Sokolowska M, Schoedel KA, et al. Assessment of the abuse potential of cebranopadol in nondependent recreational opioid users: a phase 1 randomized controlled study. J Clin Psychopharmacol. 2019;39(1):46-56. doi:10.1097/JCP.0000000000000995

97. Bohn LM, Gainetdinov RR, Lin FT, Lefkowitz RJ, Caron MG. Muopioid receptor desensitization by beta-arrestin-2 determines morphine tolerance but not dependence. Nature. 2000;408 (6813):720-723. doi:10.1038/35047086

98. Bohn LM, Lefkowitz RJ, Gainetdinov RR, Peppel K, Caron MG, Lin FT. Enhanced morphine analgesia in mice lacking beta-arrestin 2. Science. 1999;286(5449):2495-2498. doi:10.1126/science.286.5449.2 495

99. Viscusi ER, Webster L, Kuss M, et al. A randomized, phase 2 study investigating TRV130, a biased ligand of the mu-opioid receptor, for the intravenous treatment of acute pain. Pain. 2016;157 (1):264-272. doi:10.1097/j.pain.0000000000000363

100. Viscusi ER, Skobieranda F, Soergel DG, Cook E, Burt DA, Singla N. APOLLO-1: a randomized placebo and active-controlled phase III study investigating oliceridine (TRV130), a G protein-biased ligand at the micro-opioid receptor, for management of moderate-to-severe acute pain following bunionectomy. J Pain Res. 2019;12:927-943. doi:10.2147/JPR.S171013

101. Singla NK, Skobieranda F, Soergel DG, et al. APOLLO-2: a randomized, placebo and active controlled Phase III study investigating oliceridine (TRV 130), a G Protein-biased ligand at the $\mu$ opioid receptor, for management of moderate to severe acute pain following abdominoplasty. Pain Pract. 2019;19(7):715-731. doi:10.1111/papr.v19.7

102. Albert-vartanian A, Boyd MR, Hall AL, et al. Will peripherally restricted kappa-opioid receptor agonists (pKORAs) relieve pain with less opioid adverse effects and abuse potential? J Clin Pharm Ther. 2016;41(4):371-382. doi:10.1111/jcpt.2016.41. issue-4

103. Menzaghi F, Spencer R, Abrouk N, Lewis M, Chalmers D. (422) CR845, a peripheral kappa opioid, provides better pain relief with less nausea and vomiting than placebo in patients after bunionectomy. J Pain. 2015;16(4):S81. doi:10.1016/j.jpain.2015. 01.341
104. Cara Therapeutics. Cara therapeutics reports positive top-line data from adaptive phase $2 / 3$ trial of I.V. CR845 in patients undergoing abdominal surgery. 2018. Available from: https:/globenewswire.com/ news-release/2018/06/27/1530177/0/en/Cara-Therapeutics-ReportsPositive-Top-Line-Data-from-Adaptive-Phase-2-3-Trial-of -I-V-CR845-in-Patients-Undergoing-Abdominal-Surgery.html. Accessed July 31, 2019.

105. Phan NQ, Lotts T, Antal A, Bernhard JD, Stander S. Systemic kappa opioid receptor agonists in the treatment of chronic pruritus: a literature review. Acta Derm Venereol. 2012;92(5):555-560. doi:10.2340/00015555-1353

106. Brust TF, Morgenweck J, Kim SA, et al. Biased agonists of the kappa opioid receptor suppress pain and itch without causing sedation or dysphoria. Sci Signal. 2016;9(456):ra117. doi:10.1126/scisignal.aai8441

107. Roques BP, Fournie-zaluski MC, Wurm M. Inhibiting the breakdown of endogenous opioids and cannabinoids to alleviate pain. Nat Rev Drug Discov. 2012;11(4):292-310. doi:10.1038/ $\operatorname{nrd} 3673$

108. Raffa RB, Pergolizzi JV Jr., Taylor R Jr., Ossipov MH. Indirectacting strategy of opioid action instead of direct receptor activation: dual-acting enkephalinase inhibitors (DENKIs). J Clin Pharm Ther. 2018;43(4):443-449. doi:10.1111/jcpt.2018.43.issue-4

109. Wurm M, Ouimet T, Marie N, et al. DENKI (Dual Enkephalinase Inhibitors), a New Class of Painkillers Devoid of Abuse Potential and of Opiate Side-Effects. Boston, MA: International Conference on Opioids (ICOO 2018); 2018.

110. Godfrey L, Iannitelli A, Garrett NL, et al. Nanoparticulate peptide delivery exclusively to the brain produces tolerance free analgesia. J Control Release. 2018;270:135-144. doi:10.1016/j.jconrel.2017. 11.041

111. Gu ZH, Wang B, Kou ZZ, et al. Endomorphins: promising endogenous opioid peptides for the development of novel analgesics. Neurosignals. 2017;25(1):98-116. doi:10.1159/000484909

112. Webster L, Schmidt WK. Dilemma of addiction and respiratory depression in the treatment of pain: a prototypical endomorphin as a new approach. Pain Med. 2019;pii:5511538.

113. Cytogel. Cytogel Pharma announces receipt of FDA authorization to commence phase 2 development for its atypical opioid, CYT-1010. 2019. Available from: https://www.prnewswire.com/ news-releases/cytogel-pharma-announces-receipt-of-fdaauthorization-to-commence-phase-2-development-for-its-atypicalopioid-cyt-1010-300790012.html. Accessed July 31, 2019.

114. Wang D, Sun X, Sadee W. Different effects of opioid antagonists on mu-, delta-, and kappa-opioid receptors with and without agonist pretreatment. J Pharmacol Exp Ther. 2007;321(2):544-552. doi:10.1124/jpet.106.118810

115. Crabtree BL. Review of naltrexone, a long-acting opiate antagonist. Clin Pharm. 1984;3(3):273-280.

116. Verebey K, Mule SJ. Naltrexone pharmacology, pharmacokinetics, and metabolism: current status. Am J Drug Alcohol Abuse. 1975;2 (3-4):357-363. doi:10.3109/00952997509005661

117. Galloway GP, Koch M, Cello R, Smith DE. Pharmacokinetics, safety, and tolerability of a depot formulation of naltrexone in alcoholics: an open-label trial. BMC Psychiatry. 2005;5:18. doi:10.1186/1471-244X-5-18

118. Younger J, Parkitny L, McLain D. The use of low-dose naltrexone (LDN) as a novel anti-inflammatory treatment for chronic pain. Clin Rheumatol. 2014;33(4):451-459. doi:10.1007/s10067-0142517-2

119. Smith JP, Stock H, Bingaman S, Mauger D, Rogosnitzky M, Zagon IS. Low-dose naltrexone therapy improves active Crohn's disease. Am J Gastroenterol. 2007;102(4):820-828. doi:10.1111/ ajg.2007.102.issue-4 
120. Gironi M, Martinelli-boneschi F, Sacerdote P, et al. A pilot trial of low-dose naltrexone in primary progressive multiple sclerosis. Mult Scler. 2008;14(8):1076-1083. doi:10.1177/1352458508095828

121. Valentine AD, Meyers CA, Talpaz M. Treatment of neurotoxic side effects of interferon-alpha with naltrexone. Cancer Invest. 1995;13 (6):561-566. doi:10.3109/07357909509024923

122. Younger J, Mackey S. Fibromyalgia symptoms are reduced by low-dose naltrexone: a pilot study. Pain Med. 2009;10(4):663-672. doi:10.1111/j.1526-4637.2009.00613.x

123. Watkins LR, Hutchinson MR, Ledeboer A, Wieseler-frank J, Milligan ED, Maier SF, Norman Cousins Lecture. Glia as the "bad guys": implications for improving clinical pain control and the clinical utility of opioids. Brain Behav Immun. 2007;21 (2):131-146. doi:10.1016/j.bbi.2006.10.011
124. Liu SL, Li YH, Shi GY, et al. A novel inhibitory effect of naloxone on macrophage activation and atherosclerosis formation in mice. $J$ Am Coll Cardiol. 2006;48(9):1871-1879. doi:10.1016/j. jacc.2006.07.036

125. Ghai B, Bansal D, Hota D, Shah CS. Off-label, low-dose naltrexone for refractory chronic low back pain. Pain Med. 2014;15 (5):883-884. doi:10.1111/pme.12345

\section{Publish your work in this journal}

The Journal of Pain Research is an international, peer reviewed, open access, online journal that welcomes laboratory and clinical findings in the fields of pain research and the prevention and management of pain. Original research, reviews, symposium reports, hypothesis formation and commentaries are all considered for publication. The manuscript management system is completely online and includes a very quick and fair peer-review system, which is all easy to use. Visit http:// www.dovepress.com/testimonials.php to read real quotes from published authors. 